\title{
Development and design of double-layer co-injection moulded soy protein based drug delivery devices
}

\author{
Cláudia M. Vaz ${ }^{\mathrm{a}, 1}$, P.F.N.M. van Doeveren ${ }^{\mathrm{b}}$, R.L. Reis ${ }^{\mathrm{a}, \mathrm{c}}$, A.M. Cunha ${ }^{\mathrm{a}, *}$ \\ ${ }^{a}$ Department of Polymer Engineering, University of Minho, Campus de Azurém, 4800-058 Guimarães, Portugal \\ ${ }^{\mathrm{b}}$ ATO B.V., Institute of Agrotechnological Research, P.O. Box 17, 6700 AA Wageningen, The Netherlands \\ '3B's Research Group-Biomaterials, Biodegradables and Biomimetics, Department of Polymer Engineering, \\ University of Minho, Portugal, Campus de Gualtar, 4710-057 Braga, Portugal
}

Received 13 February 2003; received in revised form 28 April 2003; accepted 28 April 2003

Dedicated to Prof. Ian M. Ward on the occasion of his 75th birthday

\begin{abstract}
Novel double-layer delivery devices based on soy protein derived materials were designed and produced using an innovative two material co-injection moulding technique. It was demonstrated that the viscosity ratio between core and skin layer materials played an important role in the formation of the interfacial shape, namely the skin thickness and uniformity of the bi-materials. The adequate selection of the materials used and the optimisation of the respective processing conditions enabled an accurate control of the relative thickness of the layers of the device. The preliminary results confirmed the potential of these systems to achieve a controlled drug delivery.

(C) 2003 Elsevier Ltd. All rights reserved.
\end{abstract}

Keywords: Soy protein derived material; Mono-sandwich injection molding; Double-layer delivery device

\section{Introduction}

In the past decades, numerous methodologies have been investigated in order to produce controlled-release devices presenting zero-order release kinetics over a prolonged period of time [1-4]. These systems can maintain the drug in the desired therapeutic range with just a single dose, offering a number of advantages comparatively to the conventional-release systems [5].

In terms of formulation, monolithic matrix devices (e.g. tablets, particles, etc.) are widely used due to their easy administration and low cost of manufacturing [6]. However, these systems are incapable of attaining zero-order release, exhibiting continuously diminishing delivery rates [7, 8]. The most common approach to overcome this problem and to modify such type of release profiles is the restriction of the exposed surface. This reduces the contact with the fluids and is normally achieved by the addition of barrier layers. The production of either multi-layer tablets (by partial coating or compression coating) or core-shell particles (by

\footnotetext{
* Corresponding author. Tel.: +351-253-510-399; fax: + 351-253-510322.

E-mail address: amcunha@dep.uminho.pt (A.M. Cunha).

${ }^{1}$ Tel.: +31-40-247-4839; fax: +31-40-244-7355.
}

complex coacervation, freeze-drying, etc.) were attempted by several research groups and have been extensively investigated [9-16].

More recently, methods involving melt-based processing techniques have also been described for the preparation of this type of devices. The co-extrusion technology is a known example [17]. A less conventional approach is based on a two-material co-injection moulding technology. This technique allows the simultaneous moulding of two polymers into the desired shape, without requiring further finishing operations. The immediate result is a part with high dimensional accuracy and adjustable skin-core morphology [18]. Besides the economical advantages, the process offers: (i) suitability for a large variety of polymeric matrices; (ii) opportunity for simultaneous use of polymers of different nature; (iii) precise control of the skin-core layers' thickness by adjustment of the processing parameters; and (iv) a good interface between the two materials (if compatible matrices are used) [19-21].

Therefore, co-injection moulding may allow for the combination of a functional core material (with an encapsulated bioactive agent) with a skin layer, which will act as an effective barrier for the early drug diffusion. Since it has been shown that it is possible to produce protein 
plastics using melt-based technologies, making cost-effective products feasible, soy protein was chosen as the material for both matrices [22-25].

In fact, soy protein was selected because it can be positively distinguished from other protein-like materials, as it combines good melt processability [26,27], a reduced susceptibility to thermal degradation [26,27], low moisture sensitivity [28,29] and good storage stability [28,29].

This paper reports on the attempt to develop soy protein double-layer controlled-release devices based on this nonconventional approach. Consequently, a series of parts involving several soy matrices were co-injection moulded under optimised conditions. Rheological, mechanical and structural analysis of the produced bi-material mouldings are also presented and discussed in the manuscript.

\section{Materials and methods}

\subsection{Materials}

Soy protein isolate (amorphous, $83.4 \%$ protein, w/w on dry weight base) containing $6 \%(\mathrm{w} / \mathrm{w})$ water was purchased from Loders Crocklaan BV, The Netherlands. Glycerol and glyoxal $(40 \% \mathrm{v} / \mathrm{v})$ were used as received from the manufacturer, Sigma-Aldrich Chemie BV (Zwijndrecht, The Netherlands) used, respectively, as plasticizer and crosslinker. The polymers were reinforced with a bone-like ceramic filler hydroxylapatite (HA), namely a non-sintered grade (CAM Implants, BV, Leiden, The Netherlands) with an average particle size of $20 \mu \mathrm{m}$. This ceramic proved to provide a bioactive character to soy matrices [23], important attribute for materials aimed to be used in the biomedical field.

A 50/50 wt $\%$ blend of corn starch with an ethylenevinyl alcohol copolymer (SEVA-C, Novamont, Novara, Italy) was also used in this experiments for comparative purposes.

The model drug, theophylline $\left(\mathrm{C}_{7} \mathrm{H}_{8} \mathrm{~N}_{4} \mathrm{O}_{2}\right)$, a xanthine derivative with diuretic, cardiac stimulant and smooth muscle relaxant activities, was obtained from SigmaAldrich Chemie BV (Zwijndrecht, The Netherlands) with a purity $>98 \%$.

All the other reagents used in the experiments were of analytical grades.

\subsection{Premix preparation}

Premixes of the matrix material (soy protein isolate), fillers and drug were prepared prior to processing. The different compounds of the formulation were weighed and transferred into a mixer container. For all the compounds, the mixing operations were performed during $15 \mathrm{~min}$ at room temperature $\left(25^{\circ} \mathrm{C}\right)$ using a mixer (Bear Varimixer, Bear, Denmark) equipped with a low shear spiral-mixing tool at a speed of $45 \mathrm{rpm}$.

\subsection{Extrusion of the premix}

The premixes were converted into plastic materials by extrusion [27]. They were directly fed into a in a co-rotating twin-screw extruder (Berstorff, Hannover, Germany, $D=25 \mathrm{~mm}$ and $L=40 D$ ) and the liquids such as the plasticizers (glycerol and water) and the crosslinker (glyoxal) were concurrently injected into the feeding zone of the extruder barrel with a piston pump (Pro Minet, Verder $\mathrm{BV}$, The Netherlands). The extrusion process was performed at a screw speed of $200 \mathrm{rpm}$ and barrel temperatures ranging from 70 to $80{ }^{\circ} \mathrm{C}$. When the processing was complete, the extrudates were cooled to room temperature and cut into pellets.

Table 1 presents the codes of all the compounds prepared during this work, giving the respective formulations.

In the cases of the compounds SID and 0.6X-SID the result was the direct production of soy plastics with encapsulated theophylline drug.

The properties of the obtained compounds range from a thermoplastic to a thermoset behaviour, depending on the amount of crosslinking achieved during extrusion.

\subsection{Capillary rheometry}

The viscosity of the extruded compounds was measured using a Rosand precision advanced capillary extrusion rheometer, at $130{ }^{\circ} \mathrm{C}$. All the tested materials presented moisture content of $20 \pm 0.5 \%$. The data was obtained using a die of $1 \mathrm{~mm}$ radius and processed using the Rabinowitsch correction. The entrance effects were taken into account following the Bagley procedure.

\subsection{Co-injection moulding}

Axi-symmetrical dumbbell-like skin/core specimens of $1.5 \mathrm{~mm}$ of diameter (Fig. 1) were co-injection moulded in a two material Ferromatik-Milacron K85 machine. This machine is equipped with an $850 \mathrm{kN}$ clamping unit and two plasticating units oriented at an angle of $90^{\circ}$ to each other. The actions of the two units are independently controllable.

The machine was operated in mono-sandwich mode (Fig. 2). The injection moulding sequence includes: (i) the

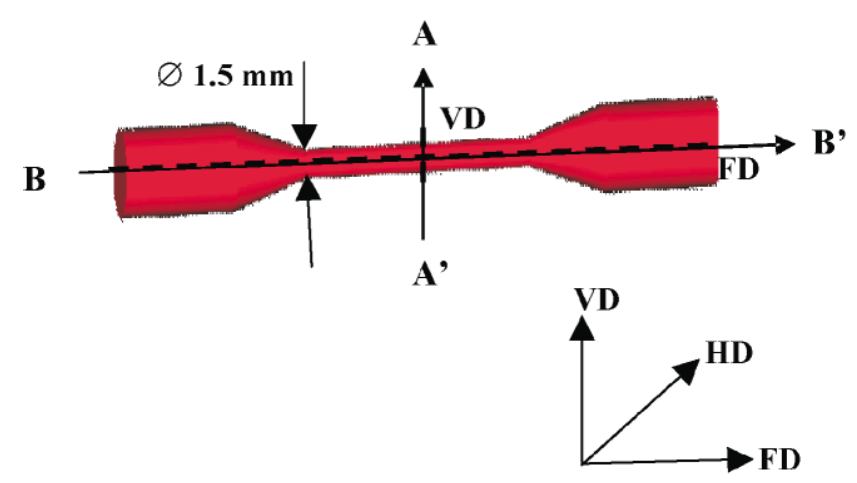

Fig. 1. Sample cutting procedures. 
Table 1

Premix formulations in phg (parts per $100 \mathrm{~g}$ of soy)

\begin{tabular}{|c|c|c|c|c|c|c|}
\hline & Soy (SI) & Glycerol (G) & Water $(\mathrm{W})$ & Glyoxal (X) & Theophylline (D) & Hydroxylapatite (HA) \\
\hline SI & 100 & 10 & 35 & - & - & - \\
\hline SID & 100 & 10 & 35 & - & 20 & - \\
\hline $0.6 \mathrm{X}-\mathrm{SI}$ & 100 & 10 & 35 & 0.6 & - & - \\
\hline $0.6 \mathrm{X}-\mathrm{SID}$ & 100 & 10 & 35 & 0.6 & 20 & - \\
\hline SI-30HA & 100 & 10 & 35 & - & - & 30 \\
\hline
\end{tabular}

independent plastication of the two materials; (ii) the extrusion of the material A (in the vertical unit) to the front of the barrel of material B (step 1); and (iii) the simultaneous injection of the two materials (step 2) due to the action of the horizontal unit [19]. As material A goes in the front, it will form the skin of the moulded part due to the contact with the cold cavity walls. Material B flows within this skin, cooling down under milder thermo-mechanical conditions and forming the core of the part.

The selected moulding geometry and the high injection velocities required to fill these bi-material specimens lead to a very specific thermo-mechanical environment, being expected high levels of heat dissipation. Shear rates during

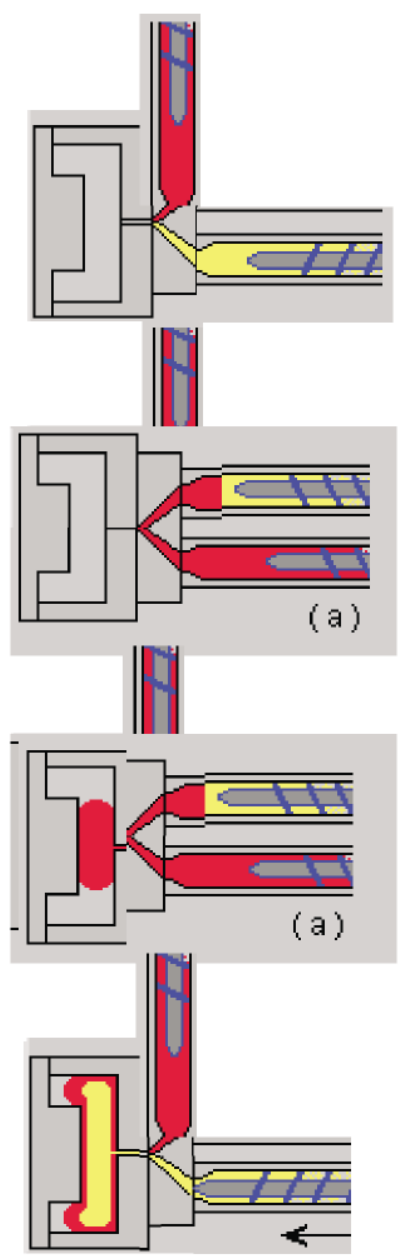

Fig. 2. Mono-sandwich operation modes. the respective filling stages are around $2 \times 10^{5} \mathrm{~s}^{-1}$. This particular situation reduced significantly the available processing window and required an accurate optimisation process.

The processing conditions used for the production of all the mouldings are indicated in Table 2. The temperature profiles of the two barrel units were, respectively: (i) vertical unit: $140 / 130 / 120 / 115 / 110 / 30{ }^{\circ} \mathrm{C}$; and (ii) horizontal unit: 140/150/145/140/135/30 ${ }^{\circ} \mathrm{C}$.

Conventional injection moulding was also performed with the SI, SI-30HA and SEVA-C materials for comparative purposes.

\subsection{Characterization of the mouldings}

The $\mathrm{SI}_{\mathrm{s}} / \mathrm{SID}_{\mathrm{c}}, \mathrm{SI}_{\mathrm{s}} / 0.6 \mathrm{X}-\mathrm{SID}_{\mathrm{c}}, \quad \mathrm{SI}-30 \mathrm{HA} \mathrm{A}_{\mathrm{s}} / \mathrm{SID}_{\mathrm{c}}$, SI$30 \mathrm{HS}_{\mathrm{s}} / 0.6 \mathrm{X}-\mathrm{SID}_{\mathrm{c}}$ and $\mathrm{SEVA}-\mathrm{C}_{\mathrm{s}} / \mathrm{SID}_{\mathrm{c}}$ bi-material mouldings were subsequently morphological and mechanically characterized (the indices $\mathrm{s}$ and $\mathrm{c}$ refer to the skin and the core materials, respectively).

\subsubsection{Morphology}

The mouldings morphology was assessed by observation of the respective sections using an Olympus SZ-ET stereoscope magnifier. The respective photographs were taken using an Olympus DP 11 digital camera.

Two cutting procedures were used to section the specimens as shown in Fig. 1. Procedure A consisted of sections perpendicular to the flow direction in the HD-VD plane. In procedure $\mathrm{B}$, the mouldings were sectioned parallel to the flow direction in the FD-VD plane, along the centre of the specimen.

\subsubsection{Mechanical properties}

2.6.2.1. Tensile tests. The mechanical behaviour of the specimens was assessed by means of tensile tests performed on a Zwick Z010 universal mechanical testing machine equipped with a $200 \mathrm{~N}$ static load cell. The selected crosshead speed was $5 \mathrm{~mm} / \mathrm{min}$ (corresponding to a strain rate of $3.33 \times 10^{-3} \mathrm{~m} \mathrm{~s}^{-1}$ ). The deformation data was obtained from a resistive extensometer. The E-modulus at $0.05-0.25 \%$ strain $\left(E_{0.05-0.25 \%}\right)$, the maximum tensile strength $\left(\sigma_{\max }\right)$ and the strain at break $\left(\epsilon_{\mathrm{b}}\right)$ were evaluated. The tensile tests were performed in a controlled environment 
Table 2

Co-injection moulding conditions

\begin{tabular}{|c|c|c|c|c|c|c|}
\hline Materials & $V_{\text {inj }}(\mathrm{mm} / \mathrm{s})$ & $P_{\text {inj }}($ bar $)$ & $t_{\text {inj }}(\mathrm{s})$ & $Q\left(\mathrm{~cm}^{3} / \mathrm{s}\right)$ & Skin:core ratio & $T_{\text {mould }}\left({ }^{\circ} \mathrm{C}\right)$ \\
\hline $\mathrm{SI}_{\mathrm{s}} / \mathrm{SID}_{\mathrm{c}}$ & 110 & 100 & 3.0 & 77.8 & $15 / 85$ & 45 \\
\hline $\mathrm{SI}_{\mathrm{s}} / 0.6 \mathrm{X}-\mathrm{SID}_{\mathrm{c}}$ & 110 & 100 & 3.0 & 77.8 & $15 / 85$ & 45 \\
\hline SI- $30 \mathrm{HA}_{\mathrm{s}} / \mathrm{SID}_{\mathrm{c}}$ & 110 & 100 & 3.0 & 77.8 & $15 / 85$ & 45 \\
\hline SI- $30 \mathrm{HA}_{\mathrm{s}} / 0.6 \mathrm{X}-\mathrm{SI}_{\mathrm{c}}$ & 110 & 100 & 3.0 & 77.8 & $15 / 85$ & 45 \\
\hline SEVA-C $\mathrm{C}_{\mathrm{s}} / \mathrm{SID}_{\mathrm{c}}$ & 120 & 120 & 3.0 & 84.8 & $17.5 / 82.5$ & 45 \\
\hline
\end{tabular}

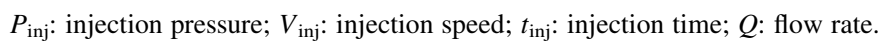

( $20^{\circ} \mathrm{C}$ and $55 \% \mathrm{RH}$ ) equivalent to the atmosphere used for conditioning the specimens during one week.

2.6.2.2. Moisture content. After testing, the fractured samples were cryogenically ground in liquid nitrogen using a Polymix A-10 (Switzerland) grinder. The ground samples were sieved to obtain powders with particle sizes $<212 \mu \mathrm{m}$, which were weighed into aluminium dishes for subsequent drying for $24 \mathrm{~h}$ in a vacuum oven at $40{ }^{\circ} \mathrm{C}$ [29]. Moisture content (MC) was determined in triplicate for each type of material as percentage of the initial weight $\left(W_{0}\right)$ lost during drying $\left(W_{0 \mathrm{~d}}\right)$ :

$\mathrm{MC}=\frac{W_{0}-W_{0 \mathrm{~d}}}{W_{0}} \times 100$

\subsubsection{Preliminary release studies}

The release kinetics of the model drug from a singlelayer device (SID) and a double-layer device $\left(\mathrm{SI}_{\mathrm{s}} / \mathrm{SID}_{\mathrm{c}}\right)$ were studied after the parallel immersion of a sample of two specimens. This was performed at $37{ }^{\circ} \mathrm{C}$, in isotonic saline solutions (ISS- $\mathrm{NaCl}, 9 \mathrm{~g} / \mathrm{l}+1 \%$ sodium azide $\left(\mathrm{NaN}_{3}\right)$ ) buffered at $\mathrm{pH} 7.4$ with $0.2 \mathrm{M}$ Tris/ $\mathrm{HCl}$. At predetermined times, $1 \mathrm{ml}$ of every solution was taken out (and replaced by $1 \mathrm{ml}$ of fresh solution) and assayed for released theophylline (D) at $273 \mathrm{~nm}$ using an HPLC/UV Waters system. The percentage of released drug was calculated from the calibration curves previously established using different theophylline standard solutions.

In order to characterize the release mechanisms associated to the different devices, a kinetic model (the Higuchi equation) was applied to the release profiles (2),

$\frac{M_{\mathrm{t}}}{M_{\infty}}=k \times t^{n}$

where $M_{\mathrm{t}} / M_{\infty}$ is the cumulative amount of drug released at time $t, k$ the release constant (dependent on the surface areas and the diffusion coefficient) and $n$ the diffusional coefficient $[1,2,4]$.

\section{Results and discussion}

\subsection{Rheological behaviour and morphology}

It has been emphasized [19] that the viscosity ratio between core and skin layer materials plays an important role in the formation of the interfacial shape, namely the skin thickness and uniformity.

The viscosity $(\eta)$ of the materials used in this study as a function of shear rate $(\dot{\gamma})$ is presented in Fig. 3 .

In Figs. 4 and 5 are presented the sandwich-like morphology of the obtained moulding. Important differences in the relative thickness of the material layers as function of the processing conditions and the selected pair of compounds are apparent.

The skin $\left(S_{\mathrm{s}} / S_{\mathrm{c}}\right)$ and the viscosity $\left(\eta_{\mathrm{c}}\right) /\left(\eta_{\mathrm{s}}\right)$ ratios were calculated for all the mouldings and are shown in Fig. 6.

These results confirm the importance of the viscosity ratio on the morphological development of the mouldings. Consequently, the following discussion is based on this parameter.

\subsubsection{Condition 1: $\eta_{\mathrm{c}} \eta_{\mathrm{s}}$}

In this specific condition, the less viscous core melt $\left(\mathrm{SID}_{\mathrm{c}}\right)$ is able to penetrate deeper through the previously formed skin material, as proved by its long flow lengths observed in Fig. 4a and c). The layers distribution is uniform and the skin thickness is relatively small (Fig. 4b and d). However, this last parameter is mainly dependent on the absolute magnitude of the viscosity of the skin material.

In fact, more viscous materials lead to the formation of thicker skin layers [30], as confirmed by the results obtained with compound SI-30HAs/SIDc, $\eta_{\mathrm{s}} / \eta_{\mathrm{c}}=0.60$ (Fig. 6). In this case, the less viscous core will experience more resistance to flow, as the effective flow section is reduced. Therefore, the respective flow length observed is smaller (Fig. 4c) when compared with the result obtained with the less viscous skin material (e.g. SIs/SID,$\eta_{\mathrm{s}} / \eta_{\mathrm{c}}=0.88$ ) (Fig. 4a).

This type of behaviour is also followed by the SEVA$\mathrm{C}_{\mathrm{S}} / \mathrm{SID}_{\mathrm{c}}$ specimens. The very high viscosity of the skin material $\left(\eta\left(\mathrm{SID}_{\mathrm{c}}\right) / \eta\left(\mathrm{SEVA}_{\mathrm{C}}\right)=0.48\right)$ inhibits the penetration core melt, thus an increment of $10 \mathrm{~m} / \mathrm{s}$ in the injection speed was required (Table 2) to obtain the 


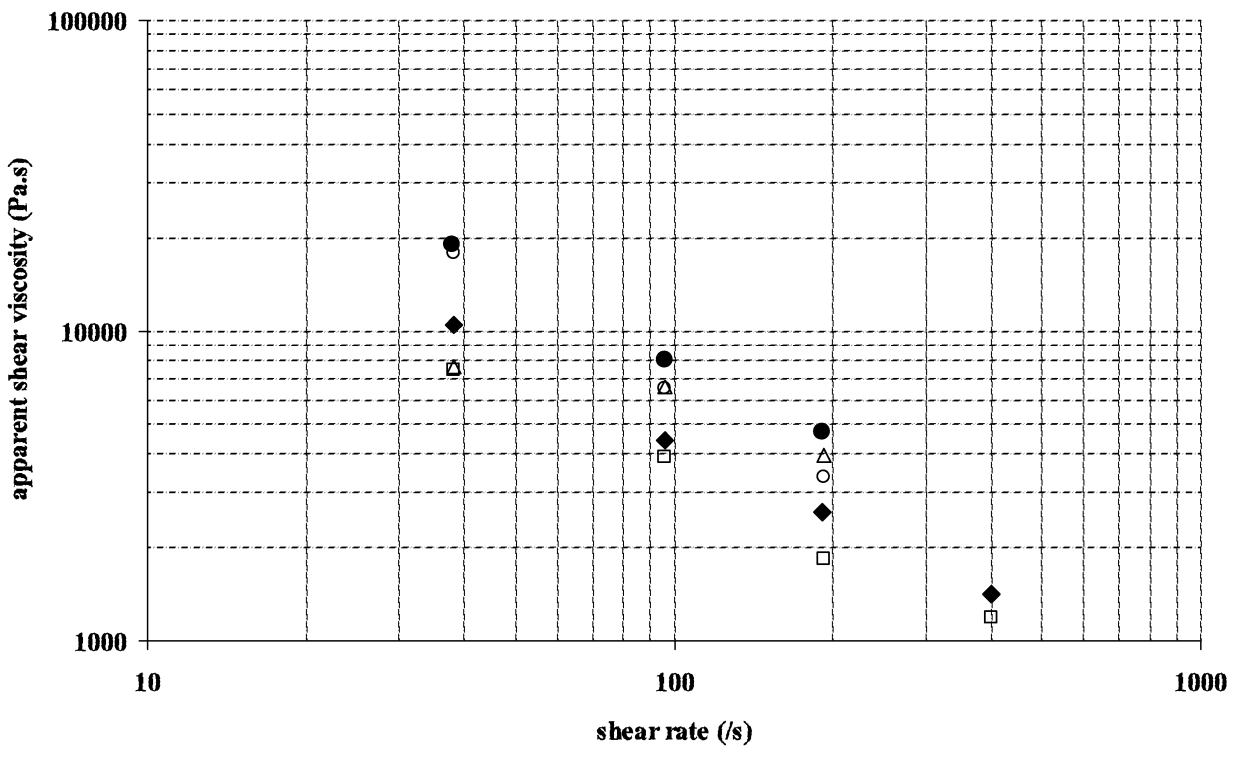

$\bullet$ SI $\square$ SID $\triangle \mathrm{X}$-SID $\circ$ SI-HA $\bullet$ SEVA-C

Fig. 3. Typical melt flow curves.
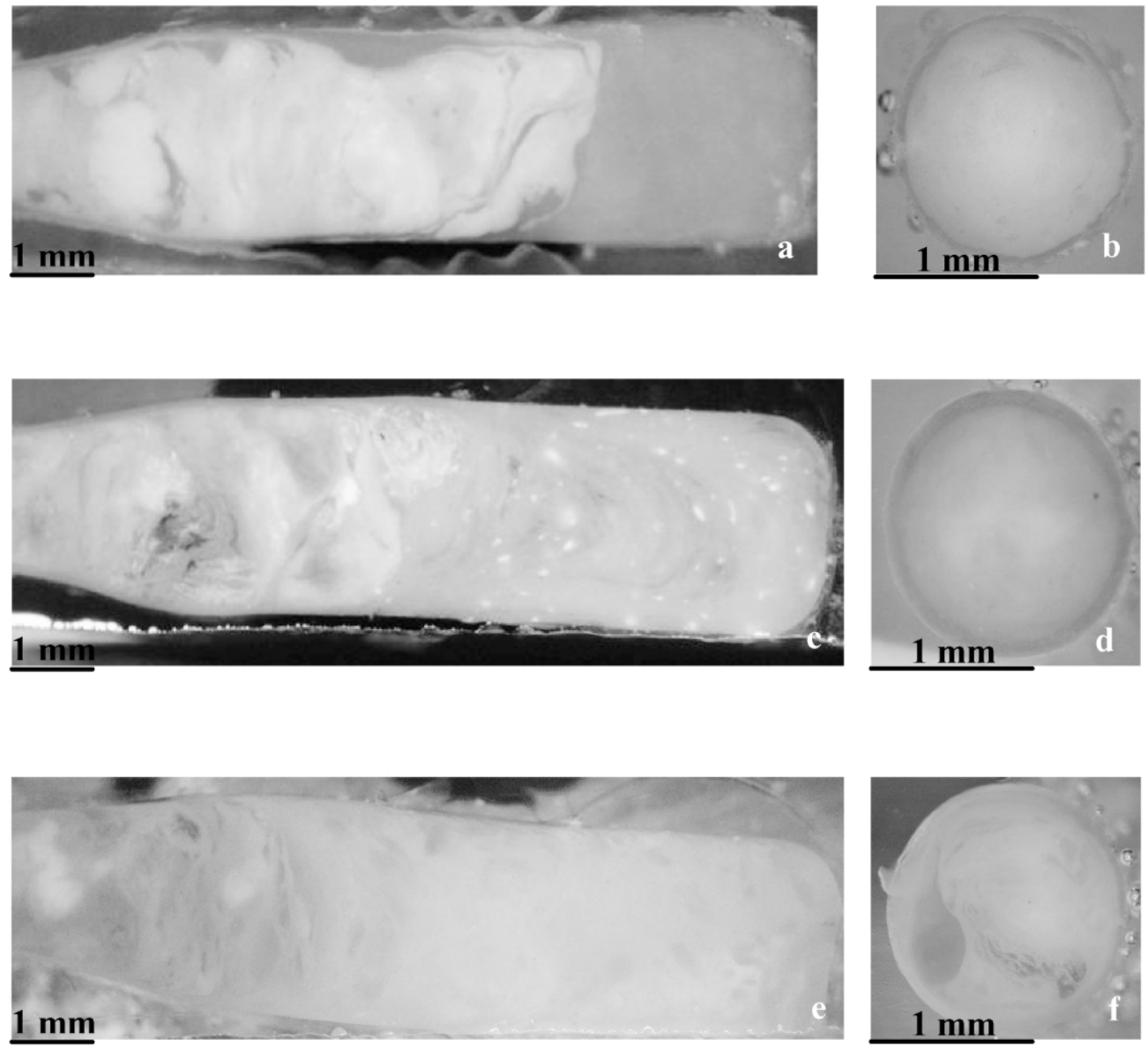

Fig. 4. Magnification of the optical sections of the mouldings: B-B' (gate side): $\mathrm{SI}_{\mathrm{s}} / \mathrm{SID}_{\mathrm{c}}(\mathrm{a}), \mathrm{SI}^{\prime}-30 \mathrm{HA} / \mathrm{SID}_{\mathrm{c}}(\mathrm{c})$ and $\mathrm{SEVA}_{\mathrm{s}} \mathrm{C}_{\mathrm{s}} / \mathrm{SID}_{\mathrm{c}}(\mathrm{e}) \mathrm{A}-\mathrm{A}^{\prime}$ : $\mathrm{SI}_{\mathrm{s}} / \mathrm{SID}_{\mathrm{c}}$ (b), SI-30HA $/ \mathrm{SID}_{\mathrm{c}}$ (d) and SEVA-C $/ \mathrm{SID}_{\mathrm{c}}$ (f). 

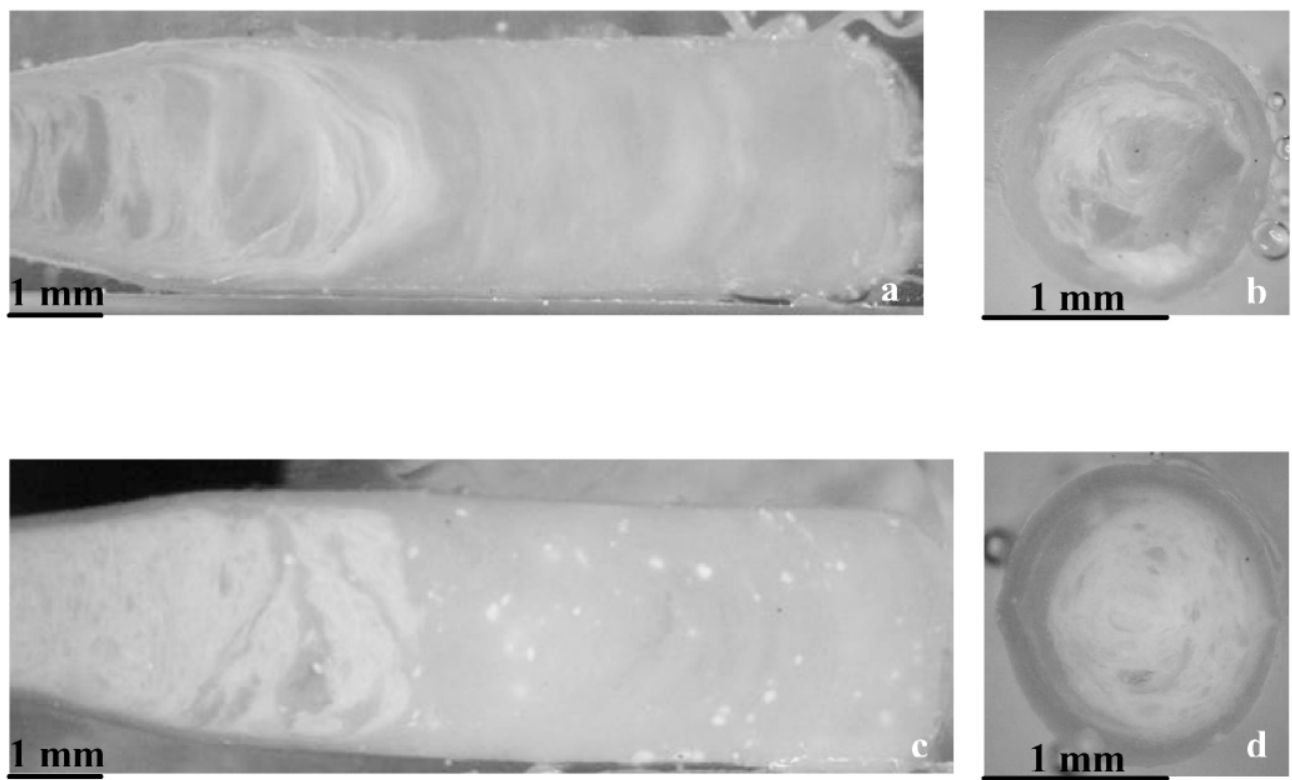

Fig. 5. Magnification of the optical sections of the mouldings: $\mathrm{B}-\mathrm{B}^{\prime}$ (gate side): $\mathrm{SI}_{\mathrm{s}} / 0.6 \mathrm{X}-\mathrm{SID}_{\mathrm{c}}$ (a) and $\mathrm{SI}-30 \mathrm{HA} \mathrm{s}_{\mathrm{s}} / 0.6 \mathrm{X}-\mathrm{SID}_{\mathrm{c}}(\mathrm{c}) \mathrm{A}-\mathrm{A}^{\prime}$ : $\mathrm{SI}_{\mathrm{s}} / 0.6 \mathrm{X}-\mathrm{SID}_{\mathrm{c}}$ (b) and SI-30HA $/ 0.6 X-$ SID $_{c}(\mathrm{~d})$.

moulding shown in Fig. 4e. Consequently, a thicker skin is also observed (Fig. 4e).

The central cross-sections (Fig. 4b, d and f) evidence the geometrical homogeneity of the obtained devices (good distribution of the core material through all part) and the possibility to control the thickness of the diffusion barrier layer (skin thickness). These are important characteristics for a system aimed to be used as controlled drug delivery device, since it can be easily tailored depending on the requisites of the target application.

\subsubsection{Condition 2: $\eta_{\mathrm{c}} \eta_{\mathrm{s}}$}

On a second condition, soy skin materials were combined with a core compound of greater viscosity (0.6X-SID C. .

The more viscous core melts (e.g. $\eta\left(0.6 \mathrm{X}-\mathrm{SID}_{\mathrm{c}}\right) /-$ $\eta\left(\mathrm{SID}_{\mathrm{s}}\right)=1.49$ and $\left.\eta\left(0.6 \mathrm{X}-\mathrm{SID}_{\mathrm{c}}\right) / \eta\left(\mathrm{SI}-30 \mathrm{HA} \mathrm{s}_{\mathrm{s}}\right)=1.02\right)$ (Fig. 6) experienced a higher flow difficulty, exhibiting shorter flow lengths, as shown in Fig. 5a and c. Possibly, the core materials tended to accumulate near the gate.

Conversely to the former condition (Section 3.1.1), these

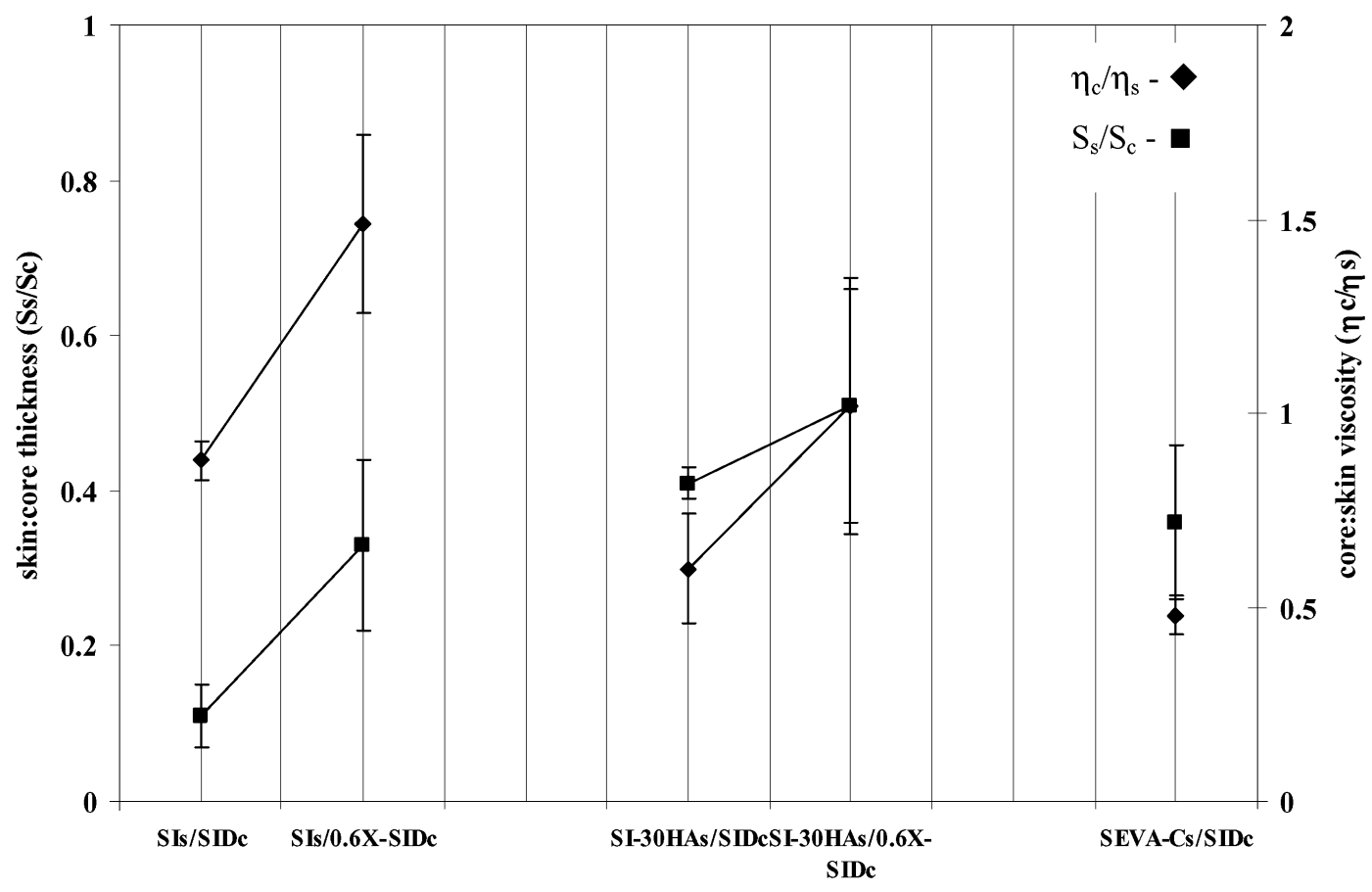

Fig. 6. Core/skin viscosity $\left.\left(\eta_{\mathrm{c}} / \eta_{\mathrm{s}}-\right)_{)}\right)$and skin/core thickness $\left(S_{\mathrm{s}} / S_{\mathrm{c}}-\mathbf{\square}\right)$ relationships of the double-layer materials. 
bi-material mouldings are characterized by a less uniform distribution of the core and by a thicker skin (Fig. $5 b$ and d).

\subsection{Mechanical properties}

The tensile properties (E-modulus, maximum strength and strain at break) of the studied bi-materials are shown in Fig. 7.

As expected, the mechanical properties of the doublelayer moulded specimens were found to be mainly dependent on the performance of the core materials. Consequently, the following analysis is associated to the
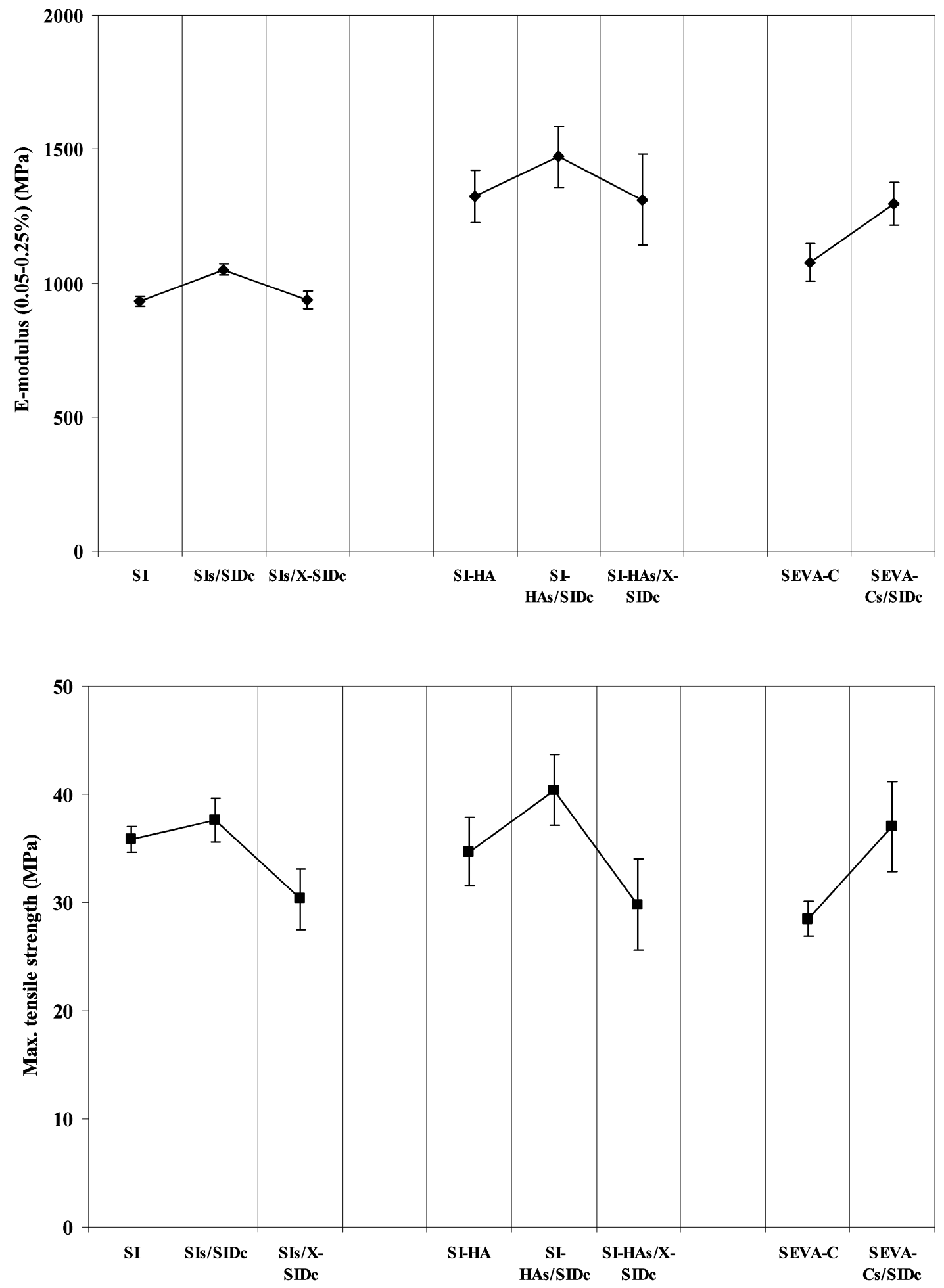

Fig. 7. Mechanical properties of the single- and double-layer moulded parts. 


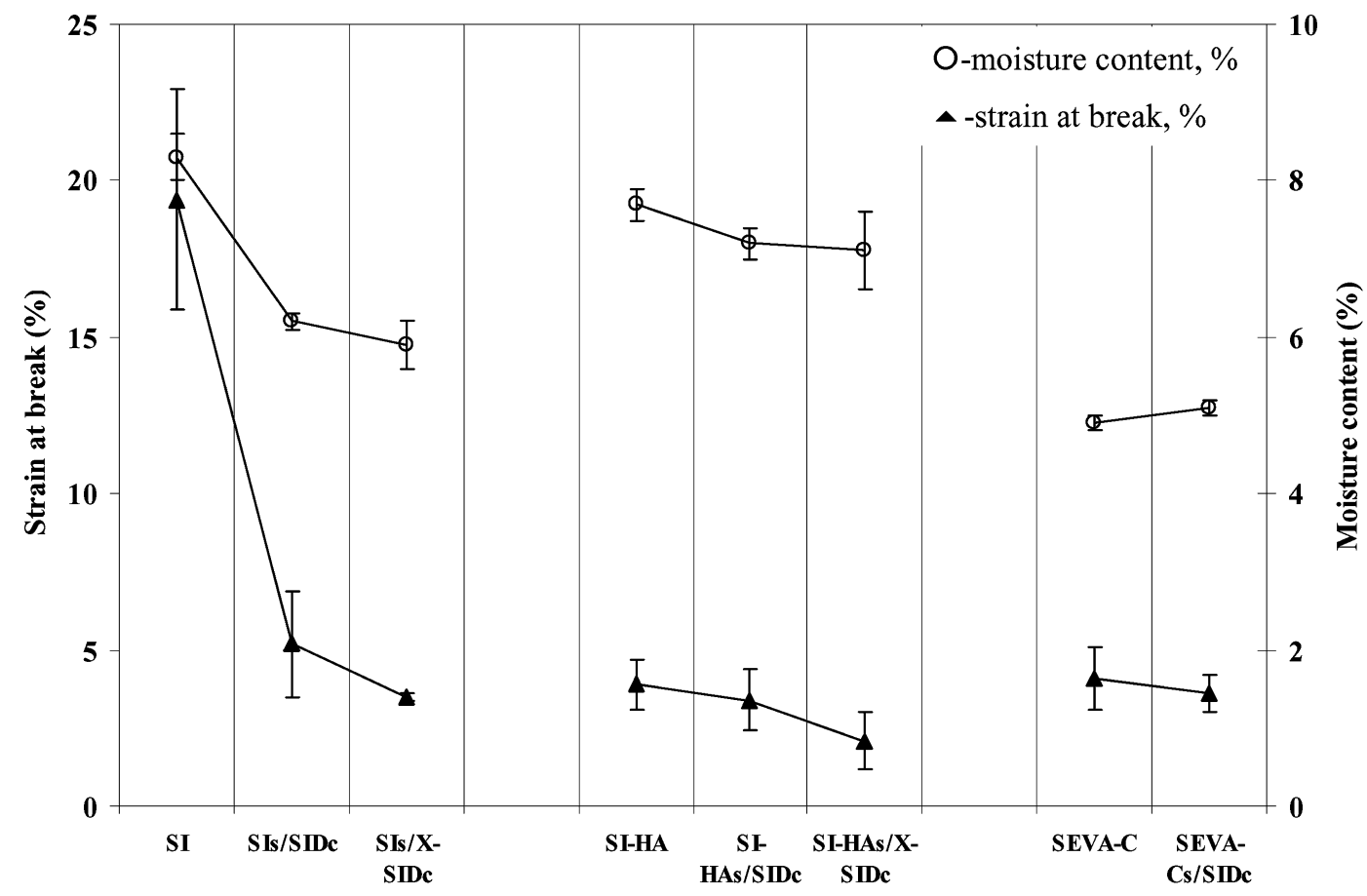

Fig. 7 (continued)

type of core selected and based on the comparison with the mono-material mouldings used as references.

\subsubsection{Core 1: soy with encapsulated drug $\left(S I D_{c}\right)$}

Compared with the respective single-layer reference parts (SI, SIHA and SEVA), the double-layer ones ( $\mathrm{SI}_{\mathrm{S}} /$ $\mathrm{SID}_{\mathrm{c}}$, SI-30HA $/ \mathrm{SID}_{\mathrm{c}}$ and SEVA-C $/ \mathrm{SID}_{\mathrm{c}}$ ) presented an increase in stiffness (between 11 and 20\%) and in tensile strength (5 and 30\%) (Fig. 7a and b). This was followed by an important decrease in the ductility, ranging from about $75 \%$ for $\mathrm{SI}_{\mathrm{S}} / \mathrm{SID}_{\mathrm{c}}$ to about $10 \%$ for $\mathrm{SI}-30 \mathrm{HA} \mathrm{s}_{\mathrm{s}} / \mathrm{SID}_{\mathrm{c}}$ and SEVA-C ${ }_{\mathrm{s}} / \mathrm{SID}_{\mathrm{c}}$ (Fig. 7c). These stiffness and strength increments are related with the reinforcement effect of the crystalline theophylline drug, present in 20 phg (parts per hundred grams of soy) in the core material.

The decrement of ductility is the combined effect of three factors: (i) the presence of the theophylline phase in the polymer matrix; (ii) the decrease in moisture content; and (iii) presence of a skin/core interface.

Although no lack of skin/core interfacial adhesion was found in the morphological observations (Fig. 4), this type of discontinuity in the bulk of the specimens is know to reduce significantly the material ductility [21].

Comparatively to $\mathrm{SI}_{\mathrm{s}} / \mathrm{SID}_{\mathrm{c}}$, the other bi-materials SI$30 \mathrm{HA}_{\mathrm{s}} / \mathrm{SID}_{\mathrm{c}}$ and SEVA-C $\mathrm{C}_{\mathrm{s}} / \mathrm{SID}_{\mathrm{c}}$ present higher stiffness, strength and brittleness (Fig. 7). This is also an expected result that should be associated to the reinforcement effect of the ceramic filler, hydroxylapatite (HA), (SI-30HA $/$ $\mathrm{SID}_{\mathrm{c}}$ ) and to the higher rigidity of the starch based compound (SEVA-C ${ }_{\mathrm{s}} / \mathrm{SID}_{\mathrm{c}}$ ) [31,32].

\subsubsection{Core 2: glyoxal crosslinked-soy with encapsulated} drug $\left(0.6 X-S I D_{c}\right)$

The use of crosslinked soy with encapsulated theophylline in the core results in double-layer parts $\left(\mathrm{SI}_{\mathrm{s}} / 0.6 \mathrm{X}-\mathrm{SID}_{\mathrm{c}}\right.$ and $\mathrm{SI}-30 \mathrm{HA}_{\mathrm{s}} / 0.6 \mathrm{X}-\mathrm{SID}_{\mathrm{c}}$ ) presenting lower values of the tensile strength and ductility relatively to the reference materials (Fig. $7 b$ and c). The variations in the stiffness are negligible relatively to the reference materials, but a decrease is observed when compared with the noncrosslinked compounds (Fig. 7a).

The significant reduction in the tensile strength (from 20 to $26 \%$, relatively to non-crosslinked materials) (Fig. $7 \mathrm{~b}$ ) is the combined result of two factors: (i) the lower core thickness of this group of mouldings; and (ii) the lower strength of the glyoxal cross-linked soy plastics.

In fact, it is already known [24] that due to the intramolecular nature of the crosslinking reaction between glyoxal and soy proteins, the resulting highly crosslinked core materials are characterized by a much lower chain mobility and, consequently, higher sensitivity to thermaldegradation during processing.

\subsection{Release behaviour}

A preliminary test was performed to compare the efficiency between a single-layer and a double-layer device to attain a zero-order release.

Fig. 8 presents the release profile of theophylline in an isotonic saline solution over a 6000 min study from a single (SID) and a double-layered $\left(\mathrm{SI}_{\mathrm{S}} / \mathrm{SID}_{\mathrm{c}}\right)$ specimens.

The single delivery device SID is mainly characterized 


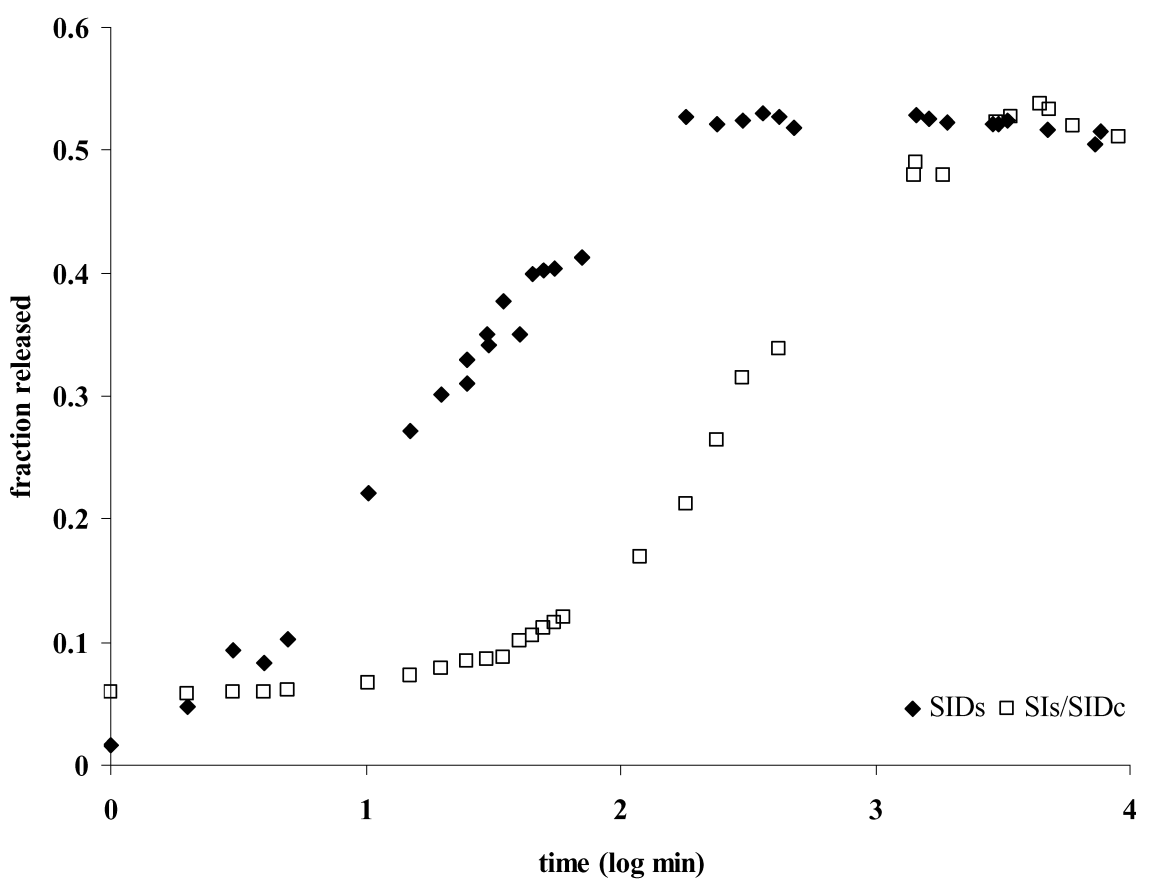

Fig. 8. Comparison between the release profiles of a single- and a double-layer device.

by an initial burst (Fig. 8). When the fraction released of theophylline is plotted against time on a $\log -\log$ scale, the diffusional exponent value $n$ is 0.50 . This indicates that theophylline releases from the soy matrix following Fickian diffusion mechanism at a release rate $(k)$ of $0.052 \pm 0.012 \mathrm{mg} \mathrm{min}^{-1}\left(0.87 \mu \mathrm{g} \mathrm{s}^{-1}\right)$

However, a controlled drug release was observed when a diffusion retardant layer $\mathrm{SI}_{\mathrm{s}}$ was used (Fig. 8). Accordingly to these results, the skin barrier layer produced by coinjection was able to delay the interaction of the core material with the dissolution medium. This layer proved to be efficient in reducing the surface available for drug release and in limiting the solvent penetration rate. Thus, the burst effect observed in the single part could be now controlled and the area available for drug release could be maintained at a relatively constant level. The final result is a device with potential application in the biomedical field as a controlled drug delivery device (slow release/fast release).

\section{Conclusions}

Prototype double-layer drug delivery devices have been designed and produced using a non-standard protein-based matrix and an innovative technique in the field, co-injection moulding. This study confirms the potential of these systems to achieve a controlled drug delivery. The adequate selection of the materials used and the optimisation of the respective processing conditions enable an accurate control of the relative thickness of the layers of the device.

The higher intricacy of these devices leads to more complex release mechanisms that need to be further evaluated in the future.

\section{References}

[1] Colombo P, Conte U, Gazzaniga A, Maggi L, Sangalli ME, Peppas NA, La Mannas A. Int J Pharm 1990;63:43-8.

[2] Colombo P, Catellani P, Peppas NA, Maggi L, Conte U. Int J Pharm 1992;88:99-109.

[3] Qiu Y, Chidambaram N, Flood K. J Control Rel 1998;51:123-30.

[4] Chidambaram N, Porter W, Flood K, Qiu Y. J Control Rel 1998;52: 149-58.

[5] Parker RS, Doyle IIIFJ. Adv Drug Deliv Rev 2001;48:211-28.

[6] Danckwerts MP. Int J Pharm 1994;112:37-45.

[7] Siepmann J, Podual K, Sriwongjanya M, Peppas. Pharm Res 1999;16: $1748-56$.

[8] Siepmann J, Podual K, Sriwongjanya M, Peppas NA, Bodmeier R. J Pharm Sci 1999;88:65-72.

[9] Yang L, Fassihi R. Int J Pharm 1999;155:219-29.

[10] Zhou T, Lewis H, Foster RE, Schwendeman S. J Control Rel 1998;55: 281-95.

[11] Ndindayino F, Vervaet C, van den Mooter G, Remon JP. Int J Pharm 2002;235:159-68.

[12] Yang L, Fassihi R. J Pharm Sci 1996;85(2):170-3.

[13] Remuñán-López C, Portero A, Vila-Jato JL, Alonso MJ. J Control Rel 1998;55:143-52.

[14] Jeong Y-I, Cheon J-B, Kim S-H, Nah J-W, Lee Y-M, Sung Y-K, Akaike T, Cho C-S. J Control Rel 1998;51:169-78.

[15] Sousa JJ, Sousa A, Moura MJ, Podczeck F, Newton JM. Int J Pharm 2002;233:111-22.

[16] Charalambopoulou G, Kikkinides ES, Papadokostaki KG, Stubos AK, Papaioannou ATh. J Control Rel 2001;70:309-19.

[17] Washburn NR, Simon Jr CG, Tona A, Elgendy HM, Karim A, Amis EJ. J Biomed Mater Res 2002;60(1):20-9.

[18] Eckardt H. J Cell Plast 1987;5:23-7.

[19] Kadota M, Cakmak M, Hamada H. Polymer 1999;40:3119-45.

[20] Selden R. Polym Engng Sci 2000;40(5):1165-76. 
[21] Bichler M, Klotz B. Kunststoffe Plast Eur 1997;October:13-16.

[22] Vaz CM, Fossen M, van Tuil RF, de Graaf LA, Reis RL, Cunha AM. J Macromol Sci Phys 2002;B41:33-46.

[23] Vaz CM, Fossen M, Tuil RF, de Graaf LA, Reis RL, Cunha AM. J Biomed Mater Res 2003;65A:60-70.

[24] Vaz CM, de Graaf LA, Reis RL, Cunha AM. Soy protein-based systems for different tissue regeneration applications. In: Reis RL, Cohn D, editors. Polymer based systems on tissue engineering, replacement and regeneration, vol. 86. Dordrecht: Kluwer Academic; 2003. p. $93-110$.

[25] Vaz CM, de Graaf LA, Mulder WF. Adhesives, coatings and bioplastics from protein sources. In: Steinbuchel A, Fahnestock SR, editors. Biopolymers: polyamides and complex proteinaceous materials II, vol. 8. Weinheim: Wiley-VCH; 2003.

[26] Sheard PR, Mitchell JR, Ledward DA. J Food Tech 1986;21:627-41.

[27] Ferreira SHP, Arêas JAG. J Food Sci 1993;58:378-81.

[28] Paetau I, Chen C-Z, Jane J. Ind Engng Chem Res 1994;33:1821-7.

[29] Wang S, Sue H-J, Jane J. J Mater Sci-Pure Appl Chem 1996;A33: 557-69.

[30] Brito AM, Cunha AM. Int Polym Proc 1991;VI(4):370-7.

[31] Reis RL, Cunha AM. J Mat Sci: Mater Med 1995;6:786-90.

[32] Reis RL, Mendes SC, Cunha AM, Bevis MJ. Polym Int 1997;43: $347-52$. 